\title{
Scenariusz średnich kosztów energii elektrycznej do roku 2050 oraz cen w taryfach za energię elektryczną dla wybranych grup odbiorców do roku 2030
}

\author{
The scenario of average costs of electricity up to 2050 \\ in Poland and forecast of electricity prices in tariffs \\ for selected groups of consumers up to 2030
}

\section{Grzegorz Wiśniewski}

\section{Andrzej Curkowski}

\section{Bartłomiej Pejas}

Instytut Energetyki Odnawialnej Sp. z o.o.

\section{Abstrakt}

A model of prices and tariffs for the Polish power system was developed, which allows assessment of the effects of public policy in the energy sector from the point of view of energy costs for the economy and for selected group of consumers. Modelling results can be used to assess the market and economic effects of individual scenarios, energy concepts or regulatory impact assessment. The model with the forecast of costs and energy prices allows to analyse the potential impact of the introduction or exclusion from the national energy system of a specific group of technologies or central power plant on electricity costs. The results of the analysis indicate the inevitability of the increase of energy costs. Domestic energy policy leads to an increase in operating costs and, as a result, to an increase in total costs in the power generation sector from PLN 37 billion in 2015 to PLN 68 billion in 2030, which will translate into an increase in tariffs for small and medium enterprises and households.

Keywords - energy balances, polish energy policy, electricity prices forecast, electricity tariffs, coal, nuclear, renewable energy, off-shore wind 


\section{Wprowadzenie}

Istnieje wiele przesłanek przemawiających za tym, że krajowy sektor energetyczny znajduje się w punkcie zwrotnym, co samo w sobie ukształtuje politykę energetyczną na następne dekady. Tymczasem brakuje wyników monitorowania polityki, przejrzystej i kompleksowej informacji o kosztach oraz wiarygodnych danych o planach aktualizacji polityki energetycznej Polski w perspektywie roku 2030 i jej możliwych kierunkach do roku 2050. Istnieje także deficyt narzędzi prognostycznych umożliwiających analizę i testowanie zapowiadanych - fragmentarycznie - założeń polityki państwa w zakresie kształtowania miksu energetycznego oraz oceny zasadności podejmowanych decyzji inwestycyjnych i analizy ich wpływu na dynamikę cen energii elektrycznej.

Potrzeba zmiany tego stanu jest niezwykle pilna. W I kwartale 2018 roku średnia hurtowa cena energii elektrycznej na Rynku Dnia Następnego (RDN) wyniosła 184 zł/MWh i była wyższa o 19\% od średniej ceny notowanej w analogicznym okresie ubiegłego roku. W II kwartale bardzo mocno wzrosły ceny energii w kontraktach terminowych na sierpień, wrzesień oraz cały trzeci kwartał 2018. Ceny przekraczały 330 zł za MWh [1]. Organa kontroli państwowej (Komisja Nadzoru Finansowego, Urząd Regulacji Energetyki, Urząd Ochrony Konkurencji i Konsumentów) zapowiadaja inspekcje na Towarowej Giełdzie Energi (TGE) oraz u głównych graczy z dominująca pozycją na rynku energii. Ich celem będzie zbadanie ewentualnych nieprawidłowości w zachowaniu podmiotów gospodarczych, ale można postawić tezę, że przyczyny wzrostu cen energii mają realne podstawy (wzrost cen węgla i szybki wzrost cen uprawnień do emisji $\mathrm{CO}_{2}$ ) i - przede wszystkim - mają charakter fundamentalny, związany z polityką energetyczna.

Konsekwencje formułowanych od kilku lat, często ad hoc, polityk i scenariuszy oraz pojedynczych decyzji inwestycyjnych, przekładają się znacząco na cała gospodarkę, jej konkurencyjność, warunki prowadzenia biznesu oraz racjonalność prowadzenia inwestycji przez wszystkich uczestników rynku energetycznego. Szczególnie silnie wpływają na działania konsumentów, prosumentów oraz prywatnych inwestorów na rzecz poprawy efektywności energetycznej i wzrostu udziału odnawialnych źródeł energii (OZE).

W najbliższym czasie zostaną podjęte zarówno na szczeblu Unii Europejskiej, jak i krajowym liczne, istotne decyzje polityczne kształtujące funkcjonowanie sektora energetycznego, m.in. dotyczące funkcjonowania tzw. rynku mocy, przyszłości gospodarki 
węglowej oraz sposobów ograniczenia emisji $\mathrm{CO}_{2}$. Brakuje jednak przejrzystej debaty o kosztach energii w krótkim, średnim i długim okresie oraz szczegółowej, kompleksowej analizy dotyczącej możliwego wpływu opracowywanych polityk energetycznych na koszty u odbiorców końcowych energii i ich skutków dla poszczególnych sektorów gospodarki. Koncepcje energetyczne są formułowane bez oceny wpływu na ceny energii oraz bez analizy wrażliwości kluczowych decyzji dotyczących politycznych prób kształtowania przyszłego miksu energetycznego.

Kluczowe decyzje, dotyczące planowania miksu energetycznego na lata 2030 i 2050 oraz wyboru poszczególnych ścieżek inwestycyjnych (m.in. elektrownia jądrowa, elektrownie na gaz ziemny, morska energetyka wiatrowa), sa przeciagane w czasie (czego dowodzi chociażby brak strategicznego dokumentu w postaci Polityki Energetycznej Polski do roku 2050, która jest już spóźniona o 7 lat), a koszty transformacji systemu energetycznego, jak również mechanizmy jej transferu do cen energii dla odbiorców końcowych nie są w pełni transparentne i rzadko bywaja przedmiotem debaty publicznej.

Liczne grono interesariuszy rynku energii, w tym zwłaszcza gospodarstwa domowe i biznesowi konsumenci energii elektrycznej, jest tym samym pozbawione dostępu do wiarygodnych informacji. Rzetelne prognozy cen energii elektrycznej są równie istotne dla administracji publicznej w zakresie oceny konsekwencji społeczno-ekonomicznych planowanych, zwłaszcza przez państwowe koncerny, inwestycji w energetyce oraz ich wpływu na gospodarkę, ale także dla prywatnych inwestycji w odnawialne źródła energii (OZE) podejmowanych przez prosumentów i przemysłowych autoproducentów energii. Narastają opóźnienia w rozwoju energetyki odnawialnej, a zwłaszcza źródeł o najniższych kosztach (słonecznych i wiatrowych), które najskuteczniej mogłyby prowadzić do obniżenia kosztów energii w średnim okresie.

Równowagi brakuje też w rozkładzie obciążeń kosztów wybranego modelu modernizacji energetyki i innych kosztów systemowych. Koszty te w największym stopniu przenoszone są na sektor małych i średnich przedsiębiorstw, działających głównie w sektorze handlu i w usługach, będących przeważnie użytkownikami taryf grupy C. Inne grupy konsumentów, tj. przemysł (grupy taryfowe B i A) oraz gospodarstwa domowych (przypisanych do taryf G), moga (przynajmniej tymczasowo) korzystać z istotnych ulg lub są przejściowo otoczone polityczną ochroną, dzięki czemu do tej pory ich taryfy utrzymywane były na relatywnie niższym poziomie (co nie znaczy, że adekwatnym do ich przychodów). Jednakże, również dla tych energochłonnych odbiorców 
przemysłowych od roku 2018 (taryfy A i B), ceny energii elektrycznej zaczynają wyraźnej rosnąć. Przy dalszym wzroście kosztów energii w systemie nie uda się utrzymać na akceptowalnym poziomie także taryf $\mathrm{G}$.

Przy braku zatwierdzonej polityki energetycznej państwowe koncerny energetyczne podejmuja „projekt po projekcie”, biznesowo, środowiskowo i społecznie ryzykowne inwestycje (w zasadzie tylko takie inwestycje są obecnie realizowane w energetyce), które przekładają się już obecnie na rosnące taryfy za energię i dystrybucję. Gdyby sumaryczne konsekwencje kosztowe podejmowanych decyzji były znane także konsumentom energii, mogliby oni - nawet przy niższym wsparciu - podejmować działania zaradcze, które mogłyby przyspieszyć rozwój efektywności energetycznej i zwiększyć dostępność nowych technologii OZE, odnotowujących największy postęp i spadek cen. Dotyczy to też sektora małych i średnich przedsiębiorstw (MŚP), w którym, przy większej świadomości fundamentalnych długoterminowych przyczyn wzrostu kosztów energii, możliwym byłoby zwiększenie skali inwestycji w fotowoltaikę typu prosumenckiego przy wysokim wskaźniku autokonsumpcji, na zasadach całkowicie rynkowych. Ale znowu, bez rzetelnej prognozy taryf energii elektrycznej inwestorom trudno jest obecnie podejmować decyzje inwestycyjne, zaś banki mogą mniej chętnie udzielać koniecznych kredytów, a wtedy inwestycje prosumenckie będą się opóźniać, a konkurencyjność firm i całej gospodarki wraz ze wzrostem kosztów energii będzie się obniżać.

Wobec niedostatecznej informacji w zakresie realizowanej przez kolejne rządy polityki energetycznej państwa i ściśle z nią powiązanych strategicznych planów inwestycyjnych, wyizolowanych koncepcji w sektorze energetycznym oraz doraźnych działań związanych ze zbilansowaniem mocy elektrowni wyłączanych z eksploatacji, autorzy artykułu podjęli się zadania monitorowania i kompleksowej analizy czynników politycznych i rynkowych, które będą kształtować lub mogą potencjalnie wpływać na ceny energii w kolejnych dekadach dla różnych grup konsumentów. Analiza czynników wpływających na koszty energii doprowadziła do opracowania modelu służącego do prognozowania cen energii i taryf na energię da poszczególnych grup odbiorców oraz do oceny polityk, mechanizmów wsparcia i skutków nowych regulacji (OSR).

Oczekuje się, że dalsze uszczegółowienie i prowadzona na bieżąco aktualizacja założeń umożliwią wykorzystanie modelu do ciagłego monitorowania polityki energetycznej, tworzenia propozycji ścieżek alternatywnych i racjonalizacji strategii inwestycyjnej wytwórców i odbiorców energii. Wyniki będą też pomocne administracji rządowej 
w monitorowaniu wpływu na koszty funkcjonowania systemu na gospodarkę i gospodarstwa domowe, wynikające z realizowanej polityki energetycznej. Może m.in. posłużyć jako narzędzie, które pomoże wnieść wkład w ocenę skutków, optymalizację oraz weryfikację Narodowego planu klimatyczno-energetycznego na lata 2021-2030, który ma zostać przyjęty przez polski rząd w roku 2018 i od którego Komisja Europejska wymaga oceny wpływu na konsumentów.

\section{Cel i zakres pracy}

Celem przeprowadzonej analizy było uzyskanie prognozy cen energii odpowiadającej najbardziej aktualnym uwarunkowaniom politycznym i rynkowym, z uwzględnieniem prowadzonych inwestycji oraz średnio i długoterminowych planów i założeń wynikajacych z krajowej polityki energetycznej. Opracowany scenariusz rozwoju systemu elektroenergetycznego, bazujacy na kosztach inwestycyjnych, operacyjnych oraz innych kosztach systemowych, z próbą podziału na grupy taryfowe dla odbiorców końcowych, oparto na krajowych planach inwestycyjnych zgodnych z zapowiedziami i polityką rządu oraz przy założeniu o utrzymaniu obecnych paradygmatów w polityce energetycznej (w pewnym zakresie odpowiadających ostatniej Polityce Energetycznej Polski do 2030 roku [2]).

Afirmatywne oparcie analiz przede wszystkim na prowadzonej polityce rządu RP, a w drugiej kolejności na rynku, uzasadnione jest wysokim upolitycznieniem ram rozwoju krajowego rynku energii elektrycznej oraz jego małą eskpozycją na politykę klimatyczną i energetyczną i w mniejszym zakresie na unijny (regionalny) rynek energii z powodu ograniczonych możliwości wymiany międzysystemowej.

Zastosowana metodyka ustalania cen hurtowych energii elektrycznej opiera się na odniesieniu do obliczonych rocznych kosztów pracy krajowego systemu energetycznego. Odbiega tym samym od stosowanego w prognozach krótkoterminowych modelu tworzenia prognoz cen „godzina po godzinie”. Różni się także od modeli dynamicznych pracy systemu, opartych na cenach giełdowych energii, nie prowadzi też wprost do ustalenia cen hurtowych energii przez graczy rynkowych. Jednoczenie dobrze opisuje skutki średnioterminowe i długoterminowe realizowanej polityki energetycznej.

Punktem wyjścia do opracowania scenariusza referencyjnego (odpowiadającego obecnie realizowanej polityce) i przeprowadzonej analizy były wyniki wcześniejszego modelowania Instytutu Energetyki Odnawialnej (IEO) sektora elektroenergetycznego 
modelem MESAP na potrzeby Dlugoterminowego scenariusza zaopatrzenia Polski w cayste nośniki energii [3] - tzw. scenariusz Energy Revolution i Analiza porónnawcza kosztón morskiej energetyki wiatrowej i energetyki jadrowej [4]. Ponadto wykorzystano historyczne dane statystyczne w zakresie cen i taryf energii elektrycznej z lat 2011-2017 publikowane przez Urząd Regulacji Energetyki (URE) i Główny Urząd Statystyczny (GUS), wskazujące na wyraźny wzrost cen dla wszystkich grup konsumentów.

\section{Konstrukcja scenariusza}

Wobec braku zatwierdzonego dokumentu Polityki energetycznej i braku kompleksowego, skonsolidowanego planu rozwoju mocy wytwórczych, analizy oparto na oficjalnych zapowiedziach dotyczących zarówno planowanych inwestycji w perspektywie średnioterminowej (scenariusz bazowy), jak i kształtu zapowiadanej przyszłej polityki energetycznej w odniesieniu do struktury mocy w perspektywie długoterminowej do 2050 roku (scenariusz referencyjny).

Za punkt startowy obrano rok 2015. Przygotowany na potrzeby analizy „scenariusz bazowy" dotyczacy inwestycji, jest odzwierciedleniem najbardziej aktualnych, oficjalnych planów inwestycyjnych przedsiębiorstw energetycznych oraz zapowiedzi Ministerstwa Energi ${ }^{1}$ (właściciela państwowych spółek energetycznych), dotyczących zarówno przyszłych trwałych odstawień źródeł wytwórczych, jak i planowanych inwestycji w nowe moce. Informacje dotyczace poszczególnych, większych inwestycji uzupełniono o skonsolidowane dane z przedsiębiorstw energetycznych zbierane w formie ankiet i publikowane w raportach operatora sieci przesyłowej - Polskie Sieci Elektroenergetyczne SA (PSE) - oraz regulatora - URE. Dane te posłużyły do opracowania kalendarium (harmonogramu), a następnie trajektorii rozwoju i modernizacji polskiego miksu energetycznego do roku 2025 (z uwagi na cykle inwestycyjne, w przypadku ogłoszonych planów w zakresie energetyki jądrowej aż do 2035 roku). Uwzględnione moce wycofywanych jednostek wytwórczych centralnie dysponowanych (JWCD) bazują też m.in. na informacjach z Giełdowej Platformy Informacyjnej oraz raporcie Najwyższej Izby Kontroli z roku 2014.

\footnotetext{
${ }^{1}$ Wykorzystano wypowiedzi kierownictwa resortu energii z lat 2016-2018 (marzec) publikowane na stronie Ministerstwa Energii, w prasie (PAP i główne dzienniki ogólnokrajowe), mediach branżowych z zakresu elektroenergetyki oraz prezentacje na konferencjach dotyczących polityki energetycznej w których oficjalnie uczestniczyli przedstawiciele Ministerstwa Energii.
} 
Kalendarium agreguje planowane inwestycje i wyłączenia z podziałem na technologie wykorzystujące poszczególne nośniki energii pierwotnej, w tym: węgiel kamienny, węgiel brunatny, gaz, paliwo jądrowe, ropę naftową i oleje opałowe, energię wody, wiatru (z podziałem na turbiny lądowe i morskie) oraz promieniowania słonecznego. Zróżnicowany technologicznie i rodzajowo miks mocy zainstalowanych i jego zmiany w analizowanym horyzoncie czasowym są wynikiem modelowania $\mathrm{z}$ wykorzystaniem aktualnych danych rynkowych (lata 2015 i 2017) oraz inwestycji objętych stworzonym kalendarium (2018-2035). Przyrost mocy OZE został oszacowany na podstawie wyników przeprowadzonych oraz zaplanowanych aukcji na nowe moce ${ }^{2}$ oraz tzw. aukcji migracyjnych, które wpływają na koszty nie zmieniając struktury mocy wytwórczych. Wyniki istniejących i już znanych planów inwestycyjnych (łącznie z planami odstawień) przedstawia rysunek 1 .

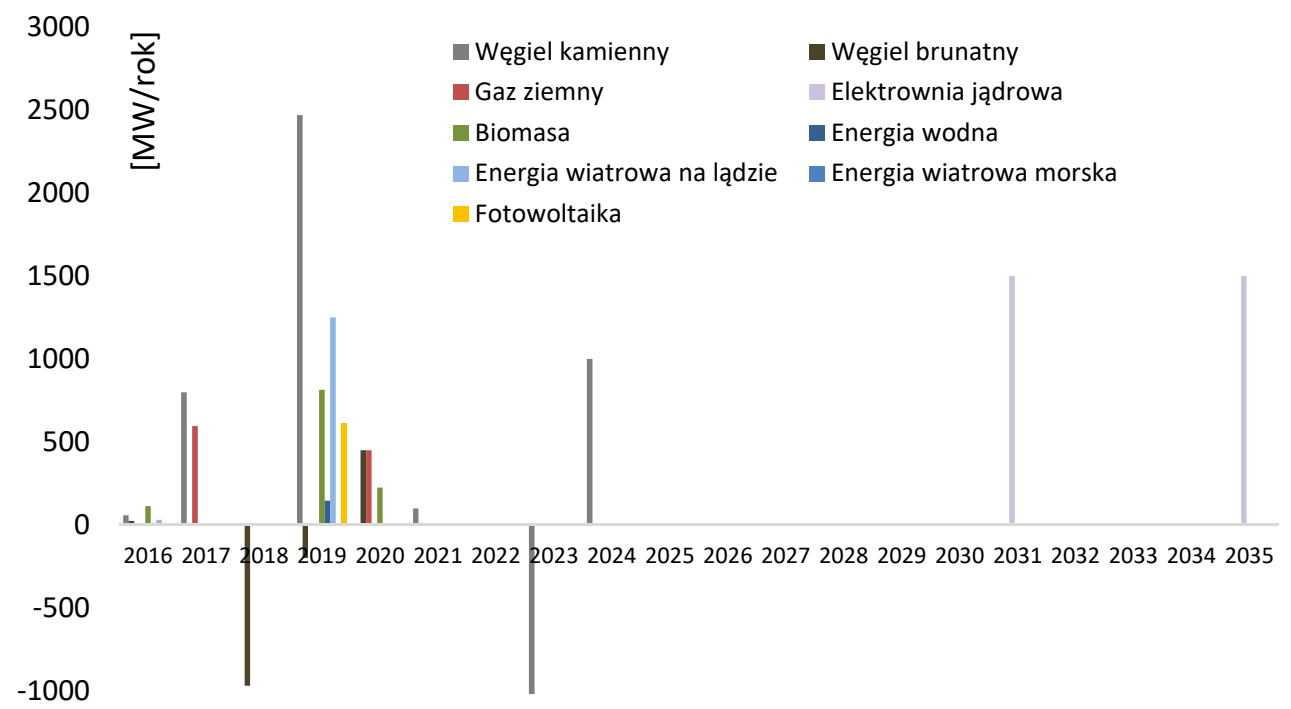

Rysunek 1. Kalendarium wyłączeń i nowych mocy wprowadzanych do krajowego systemu energetycznego (KSE) w oparciu o istniejące plany inwestycyjne przedsiębiorstw energetycznych

Oficjalne plany inwestycyjne, skutkujące w okresie kolejnych 20 lat nowymi mocami, sa stosunkowo skromne i niepełne, gdyż nie uwzględniają budowy i odstawień mniejszych

\footnotetext{
${ }^{2}$ W analizach uwzględniono wyniki aukcji na energię z OZE z lat 2016-2017 oraz plan aukcji zapowiedziany na rok 2018 w projekcie rządowym nowelizacji ustawy o OZE z marca 2018 r.
} 
źródeł. Dla zapewnienia pełnego pokrycia krajowych potrzeb w dłuższej perspektywie w stosunku do założeń wynikających z kalendarium, scenariusz bazowy wymagał uwzględnienia dodatkowych, jeszcze nie w pełni zidentyfikowanych inwestycji, w szczególności w rozproszone źródła OZE oraz m.in. w morską energetykę wiatrową, które stanowić będą konieczne uzupełnienia braków w strukturze wytwarzania. Nowe moce instalacji OZE uzupełniono o szacunkowe, zgodne z obecnie realizowana polityką wobec prosumentów, roczne przyrosty w sektorze mikroinstalacji. Uwzględniono też rozproszone źródła gazowe.

Do kalendarium inwestycji włączono zaawansowane projekty i jeszcze nieoficjalne plany Polskiej Grupy Energetycznej SA (jeszcze nie potwierdzone przez Ministerstwo Energii) i Grupy Polenergia w zakresie morskiej energetyki wiatrowej. W związu z brakiem decyzji o inwestycji w elektrownie oparte na węglu brunatnym (nowe odkrywki), nie zostały one uwzględnione w zweryfikowanym kalendarium. Ostatnią nową elektrownią opartą na węglu kamiennym pozostała (zgodnie z planami przedsiębiorstw i zapowiedzią Ministerstwa Energii), Elektrownia Ostrołęka. Wyłączenia innych niż JWCD (mniejszych) jednostek wytwórczych zostały oszacowane w oparciu o wartości mocy zainstalowanych wymagających w najbliższym czasie wyłączenia lub zastapienia (tzw. repowering) ze względu na stopień wyeksploatowania poszczególnych obiektów (przyjęto średnie okresy życia dla danych technologii). Wyniki przedstawiono na rysunku 2.

Inwestycje te mieszczą się w dotychczasowych założeniach rządu dotyczących zapotrzebowania na energię i są uwzględnione w perspektywie roku 2030 (2035) w scenariuszu referencyjnym struktury miksu energetycznego w perspektywie długookresowej. Informacje na ten temat pojawiły się w IV kwartale 2017 roku, gdy po rozmowach z Komisją Europejską nt. ustawy o rynku mocy i o OZE oraz analizach dotyczących możliwości spełnienia przez Polskę nowych celów klimatycznych zawartych w „Pakiecie zimowym” [5], Ministerstwo Energii zapowiedziało ramy nowej polityki energetycznej (zapotrzebowanie na energię elektryczna) i miksu energetycznego do 2050 roku, z propozycją spełnienia przez Polskę norm międzynarodowych i wymogów środowiskowych do roku 2030. 


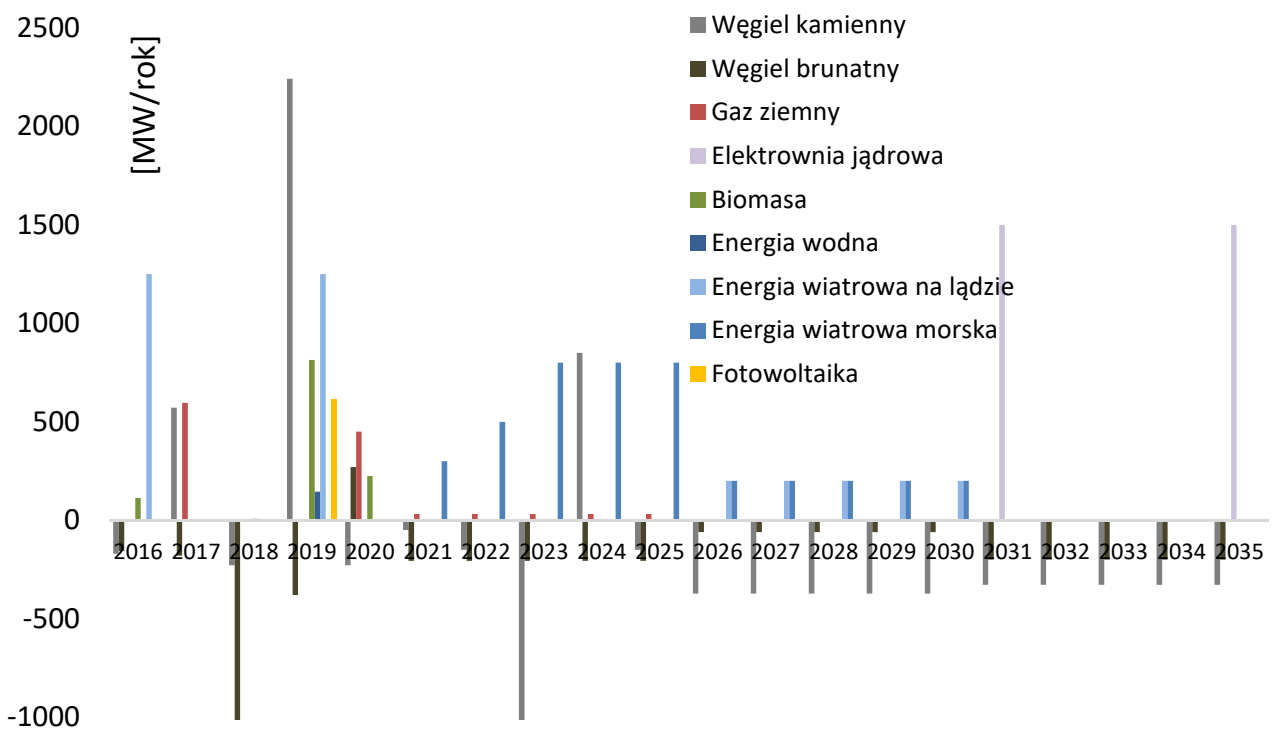

Rysunek 2. Bilans zweryfikowanych wyłączeń i nowych mocy wprowadzanych do KSE w rozpatrywanym scenariuszu bazowym w oparciu o istniejące plany inwestycyjne wraz z dodatkowymi założeniami uzupełniającymi.

Zarysowana (jedynie w mediach i na konferencjach) przez Ministerstwo Energii struktura nowych mocy była przedmiotem weryfikacji i możliwości optymalizacji, przy uwzględnieniu ramowych kryteriów, takich jak zapewnienie odpowiedniej rezerwy mocy oraz potencjału wzrostu udziału zależnych od pogody źródeł OZE. Uwzględniając zidentyfikowane plany wycofań i budowy nowych jednostek wytwórczych, w oparciu o bilans zapotrzebowania na energię elektryczną według Ministerstwa Energii wraz z koniecznymi uzupełnieniami o dodatkowe nowe moce, powstał scenariusz referencyjny stanowiący realizację aktualnej polityki w perspektywie roku 2050 - rysunek 3.

Najbardziej charakterystycznym i znaczącym (również najbardziej kosztownym) elementem w strukturze nowych mocy jest energetyka jądrowa, która według zapowiedzi Ministerstwa Energii ma się pojawić w miksie energetycznym już w roku 2031. Na potrzeby dalszego wariantowania scenariusza referencyjnego (możliwości zastapienia energetyki jądrowej) i późniejszej oceny wpływu (analiza wrażliwości) kształtu miksu energetycznego na koszty energii, scenariusz ten oznaczono jako „scenariusz referencyjny" ATOM’2031. 
$80 \mathrm{GW}$

$70 \mathrm{GW}$

$60 \mathrm{GW}$

$49 \mathrm{GW} \quad 51 \mathrm{GW} \quad 53 \mathrm{GW} \quad 53 \mathrm{GW}$

$50 \mathrm{GW}$

$40 \mathrm{GW}$

$30 \mathrm{GW}$

$20 \mathrm{GW}$

$10 \mathrm{GW}$

$0 \mathrm{GW}$

$55 \mathrm{GW}$

$55 \mathrm{GW} \quad 56 \mathrm{GW}$
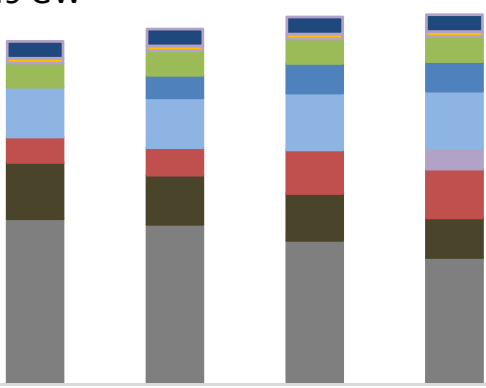

$2015 \quad 2020$

Węgiel kamienny

2025

2030

2035

Węgiel brunatny

Elektrownia jądrowa

Energia wiatrowa na lądzie

Fotowoltaika

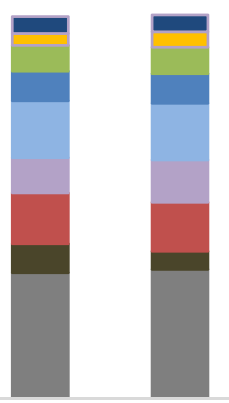

2040

2045

Gaz ziemny

Biomasa
Energia wiatrowa morska

- Energia wodna

Rysunek 3. Trajektoria rozwoju miksu mocy w KSE w scenariuszu referencyjnym (odpowiadającym obecnym planom inwestycyjnym przedsiębiorstw i zapowiedziom Ministerstwa Energii)

Uzyskany scenariusz przyrostu i zmian struktury mocy wytwórczych w krajowym systemie energetycznym (KSE), wraz z odpowiednimi nakładami inwestycyjnymi oraz uwzględnieniem stopnia wykorzystania mocy, kosztów eksploatacyjnych (w tym paliw, podatków i opłat), stał się podstawą do określenia struktury wytwarzania energii elektrycznej, która z kolei posłużyła do określenia kosztu wytworzenia jednostki energii elektrycznej ze źródeł krajowych w analizowanej perspektywie. W analizach przyjęto, że w bilansach rocznych energii źródła krajowe wytwórcze zapewnia pokrycie krajowego zapotrzebowania na energię (zerowe saldo wymiany energii elektrycznej z zagranica).

\section{Założenia przyjęte do obliczeń}

Wykorzystywany model obliczeniowy, opierający się na projekcji przyszłych kosztów generacji energii elektrycznej dla każdego roku prognozy, w oparciu o stworzony scenariusz referencyjny (ATOM'2031) rozwoju mocy wytwórczych w KSE, wyznacza średni koszt produkcji energii elektrycznej dla każdej z technologii oraz dla całego systemu elektroenergetycznego. Podstawowe założenia oraz dane wejściowe przyjęte 
w celu przeprowadzania modelowania kosztów energii w oparciu o scenariusz referencyjny obejmowały następujące parametry ekonomiczne i ograniczenia techniczne:

- nakłady inwestycyjne związane z mocami wprowadzanymi do systemu;

- koszty operacyjne stałe, związane z bieżącą eksploatacją jednostek wytwórczych;

- koszty operacyjne zmienne, związane ze zużyciem paliw oraz uprawnień do emisji $\mathrm{CO}_{2}$ do atmosfery;

- koszty kapitału oraz założenia finansowe;

- założenia techniczne i eksploatacyjne, wynikające z pracy źródeł w zbilansowanym systemie (KSE).

Uzyskany w wyniku symulacji uśredniony koszt generacji energii elektrycznej został dodatkowo obciążony uśrednioną marżą przedsiębiorstw wytwórczych, co pozwoliło na określenie średniej ceny sprzedaży energii elektrycznej na rynku hurtowym, która zapewnia pokrycie kosztów w całym systemie. Autorzy, bazując na trendach, dokonali też przełożenia średniej sprzedaży energii elektrycznej na prognozę dostaw cen energii poszczególnym odbiorcom końcowym (prognoza cen energii dla poszczególnych grup taryfowych).

Założenia nie uwzględniają w tym miejscu konieczności „nadążnego” za wzrostem mocy w jednostkach scentralizowanych nakładów na rozwój sieci energetycznych. Koszty te sa przynajmniej częściowo - jako kontynuacja obecnych trendów na rzecz budowy centralnych jednostek wytwórczych - uwzględnione w dalszej części analiz. Podkreślenia wymaga jednak fakt, że gdyby model rozwoju generacji w analizowanym scenariuszu był mniej scentralizowany i dążył w kierunku generacji rozproszonej, koszty rozwoju sieci byłyby nisze.

\section{Koszty nośników energii}

Prognozę cen nośników energii (w przeliczeniu na euro, w cenach stałych z roku 2017), przyjęto na podstawie scenariusza Energy Revolution IEO [3] (biomasa), opracowań Ministerstwa Energii [6] (węgiel) oraz prognoz cen gazu i paliwa uranowego wg IEA [7] - rysunek 4. 
20

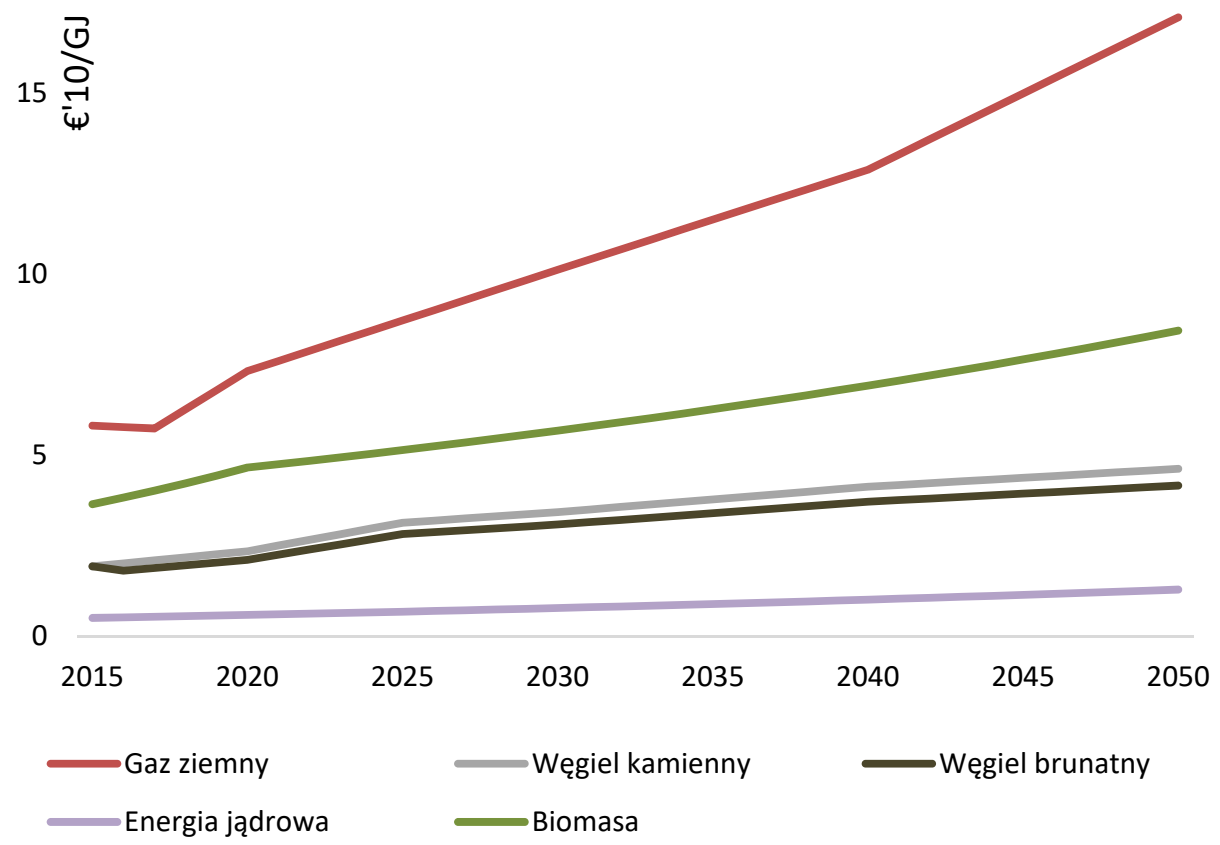

Rysunek 4. Scenariusz kosztów paliw. Koszty paliw na wykresie podano w euro, w cenach stałych z roku $2010\left(\epsilon^{\prime} 10\right)$.

Ceny uprawnień do emisji $\mathrm{CO}_{2}$

Emisyjność $\mathrm{CO}_{2}$ z poszczególnych paliw została przyjęta zgodnie z opracowaniem KOBiZE Wartości opatowe (WO) i wskaźniki emisji CO2 (WE) w roku 2014 do raportowania w ramach Systemu Handlu Uprawnieniami do Emisji za rok 2017 [9]. Do określenia cen uprawnień do emisji $\mathrm{CO}_{2}$ wykorzystano jedną z najbardziej umiarkowanych, mieszczących się w dolnym paśmie średniej z wielu innych prognoz tworzonych na rynek UE, prognoze Thomson Reuters [8]. Wyniki analizy przedstawia rysunek 5. 


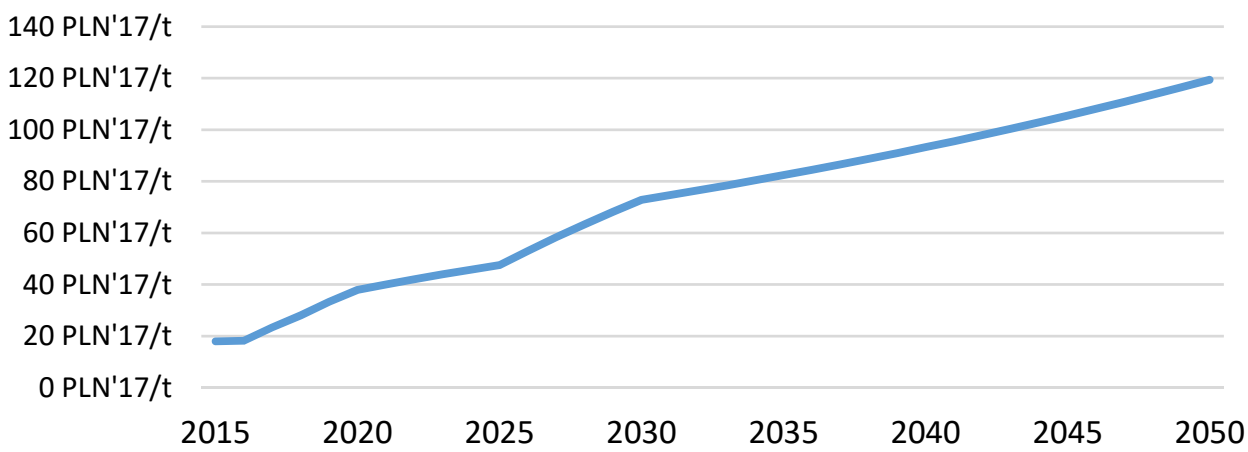

Rysunek 5. Koszty uprawnień do emisji CO2 w perspektywie roku 2050. Koszty uprawnień podano w cenach stałych w polskich złotych z roku 2017 (PLN'17).

Źródło: [9].

Założenia finansowe i eksploatacyjne

Tabela 1. Parametry finansowe i eksploatacyjne dla poszczególnych technologii pozyskiwania energii

\begin{tabular}{lccc} 
Technologia & WACC $^{\text {a }}$ [\%] & $\begin{array}{c}\text { Wskaźnik } \\
\text { konwersji [\%] }\end{array}$ & $\begin{array}{c}\text { Czas eksploatacjib } \\
\text { [lata] }\end{array}$ \\
Węgiel kamienny & 10,7 & 36 & 35 \\
\hline Węgiel brunatny & 10,7 & 34 & 35 \\
\hline Gaz & 5,0 & 50 & 25 \\
\hline Olej opałowy & 5,0 & 36 & 25 \\
\hline Biomasa & 5,0 & 25 & 20 \\
\hline Energia jądrowa & 10,7 & 30 & 40 \\
\hline Elektrownie wodne & 5,0 & $-{ }^{c}$ & 60 \\
\hline Energia wiatrowa lądowa & 5,0 & $-{ }^{c}$ & 20 \\
\hline Energia wiatrowa morska & 5,0 & $-{ }^{c}$ & 20 \\
\hline Fotowoltaika & 5,0 & $-c$ & \\
\hline
\end{tabular}

a WACC - ang. Weighted Average Cost of Capital, średni ważony koszt kapitału własnego (inwestora) i kredytu bankowego.

b Średni okres eksploatacji źródeł wytwórczych w danej technologii - całkowite okresy eksploatacji do momentu odstawienia.

${ }^{c}$ W przypadku elektrowni wodnych, farm wiatrowych i słonecznych przyjęto, że energia pierwotna równa się energii końcowej. 
- Wskaźniki finansowe:

- inflacja - przyjęto średni wzrost cen usług $1 \%$ rocznie,

- kredytowanie - okres kredytowania inwestycji - 20 lat;

- Poprawa sprawności nowobudowanych źródeł energii.

O ile wskaźniki WACC i okresy eksploatacji założono niezmienne w całym okresie analizy, o tyle w przypadku sprawności źródeł wytwórczych uwzględniono, że sprawności wprowadzanych do sytemu nowych źródeł wytwórczych w energetyce będą rosły corocznie liniowo dla wszystkich technologii o 0,5\% (r/r). Chodzi o średnią ważoną z miksu energetycznego (w praktyce poprawa sprawności źródeł OZE jest znacznie szybsza niż źródeł węglowych).

- Koszty energii elektrycznej ze źródeł kogeneracyjnych.

Uwzględniono specyfikę źródeł kogeneracyjnych w kosztach systemu elektroenergetycznego, poprzez obniżenie wskaźników kosztów energii elektrycznej w źródłach kogeneracyjnych w formie ,kredytowania” cen uzyskiwanych za energię elektrycznej przez przychody ze sprzedaży ciepła w systemach współwytwarzania energii elektrycznej i ciepła. Za [3] przyjęto, że tzw. heat credit’ odpowiada prognozowanym wartościom ciepła z kogeneracji w przeliczeniu na ceny stałe z roku 2017 (zł’17/GJ):

$$
\begin{aligned}
& \text { - 44,70 zł'17/GJ (2020), } \\
& \text { - 48,10 zł’17/GJ (2025), } \\
& \text { - 51,70 zł’17/GJ (2030), } \\
& \text { - 55,95 zł'17/GJ (2040), } \\
& \text { - 60,82 zł'17/GJ (2050). }
\end{aligned}
$$

- Współczynniki rocznego wykorzystania mocy zainstalowanej (tzw. capacity factors $-\mathrm{CF})$.

Wartości CF podlegają systematycznym zmianom, które są nie tylko związane z ciagła poprawą charakterystyk technicznych źródeł wytwórczych (w szczególności w przypadku OZE), ale też zmieniają się pod wpływem zmian struktury tworzonego miksu, w zależności od kosztów wytwarzanej energii (w szczególności ich składowej zmiennej) oraz przyjętego modelu regulacyjnego na rynku energii. Są więc złożoną funkcją uwikłaną wielu zmiennych. Dokładne wartości współczynników CF dla poszczególnych rodzajów, grup technologii i źródeł działających obecnie w KSE nie są podawane do

\footnotetext{
${ }^{3}$ Heat credit-odliczenia za wartość ciepła z elektrociepłowni, według [3].
} 
informacji publicznej. Jednak dotychczasowe trendy dla danych rodzajów źródeł wydaja się dobrym punktem wyjścia do ich oceny i ekstrapolacji wartości współczynników wykorzystania mocy w perspektywie średniookresowej (w perspektywie długookresowej zadecydują o tym koszty i zasady bezpiecznego funkcjonowania europejskiego systemu energetycznego).

$\mathrm{Na}$ podstawie scenariusza bazowego ze strukturą miksu mocy wytwórczych oraz rzeczywistych danych rynkowych za lata 2015-2016 w zakresie mocy zainstalowanej i produkcji energii w poszczególnych grupach źródeł, dokonano kalibracji modelu obliczeniowego oraz wyznaczono współczynniki wykorzystania mocy zainstalowanej CF dla każdej technologii. Przebieg zmienności współczynników CF dla poszczególnych technologii w kolejnych latach w perspektywie roku 2030 wyznaczono na podstawie analiz własnych sektora wytwarzania energii elektrycznej z OZE oraz opracowań branżowych (w przypadku elektrowni węglowych).

Zgodnie z biznesplanami inwestorów przyjęto dość optymistycznie, że do lat 20242025 współczynnik CF elektrowni węglowych będzie utrzymywał się na stałym poziomie, a później będzie rósł. $\mathrm{W}$ ten sposób, zgodnie z deklarowaną polityką, zaznaczony został wpływ wejścia do systemu nowych bloków o dużej mocy, które będa pracowały z dużym stopniem wykorzystania mocy.

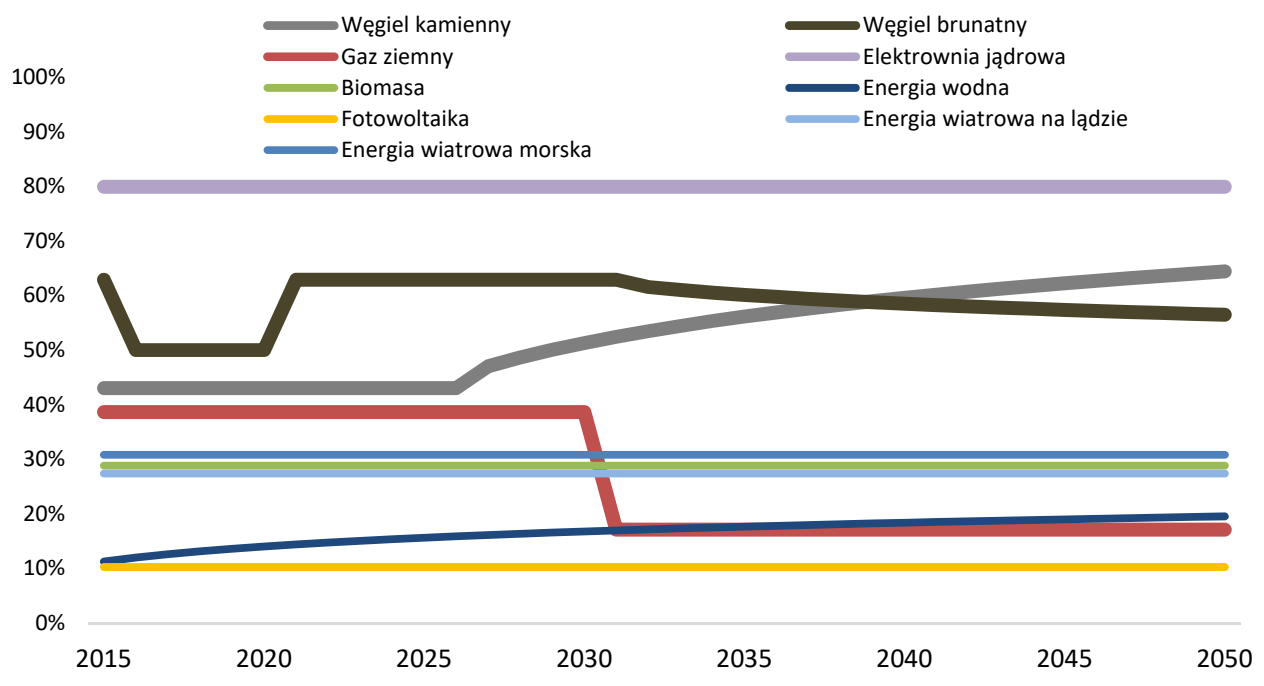

Rysunek 6. Zmienność współczynników CF w czasie wynikająca z założeń do prognozy 
Ponadto założono, że wprowadzony rynek mocy doprowadzi do modernizacji istniejących jednostek, przez co również zwiększy się ich poziom wykorzystania mocy. Odnośnie elektrowni opalanych węglem brunatnym przyjęto też optymistycznie, że derogacje pozwolą utrzymać wytwórcom energii elektrycznej z węgla brunatnego stały stopień wykorzystania mocy zainstalowanej do ok. 2030 roku, natomiast później jego wartość będzie spadać. Moce gazowe coraz bardziej będa przejmować rolę źródeł szczytowych, a ich stopień wykorzystania mocy, w momencie wejścia do systemu elektrowni jądrowych, spadnie. Ilustracją powyższych założeń jest rysunek 6 .

\section{Struktura wytwarzania energii elektrycznej wg scenariusza referencyjnego}

Powyższe założenia, w szczególności dotyczące paramentów eksploatacyjnych, wprowadzone do prognozy rozwoju mocy wytwórczych KSE (por. rys. 2) pozwoliły na określnie struktury wytwarzania energii elektrycznej do roku 2050. Zgodnie z zapowiedziami Ministerstwa Energii, w porównaniu z rokiem 2015, w roku 2030 produkcja energii elektrycznej wzrośnie o 17\% (wzrośnie ze 162 do 189 TWh). Strukturę wytwarzania energii elektrycznej przedstawiono na rysunku 7.

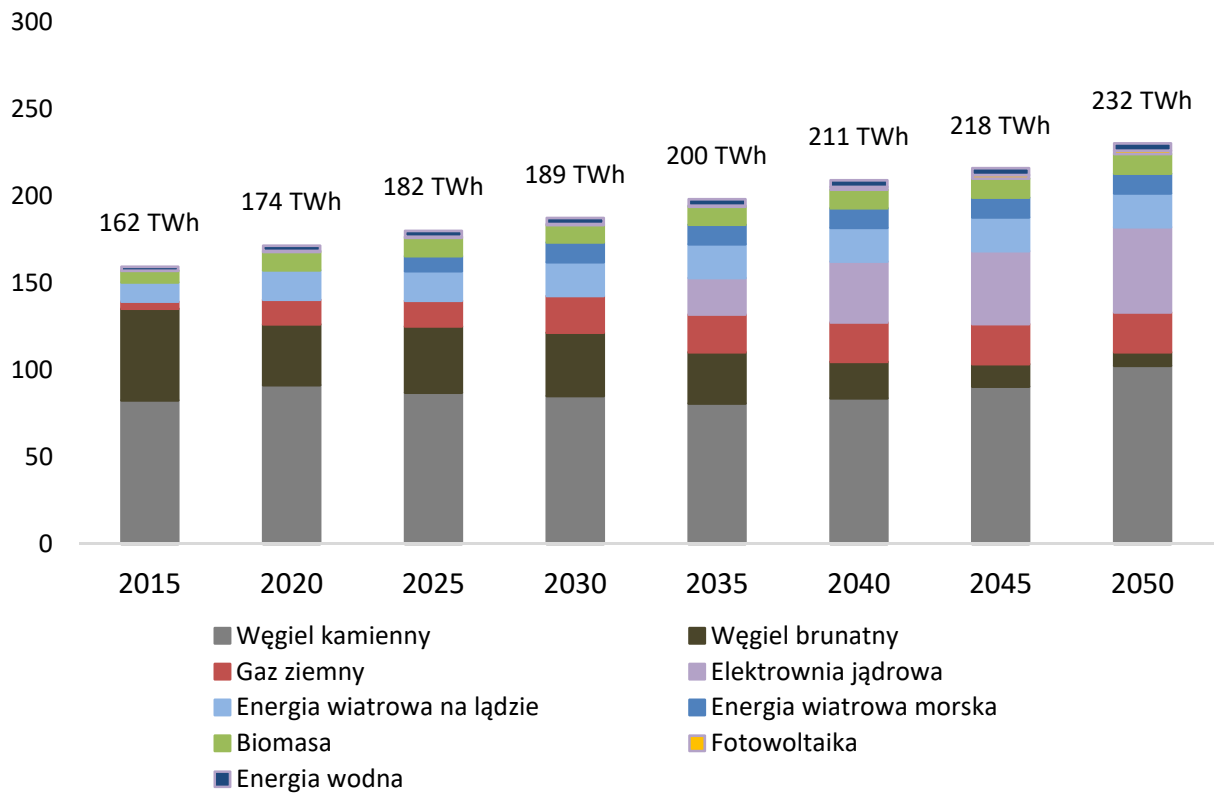

Rysunek 7. Krajowy miks energetyczny w okresie prognozy wg scenariusza referencyjnego ATOM'2031 
Uzyskana struktura wytwarzania energii pozwala jednak na obniżenie średniej emisji $\mathrm{CO}_{2}$ systemu energetycznego poniżej wartości $500 \mathrm{~g} \mathrm{CO}_{2} / \mathrm{kWh}$ (rysunek 8), umożliwiając spełnienie wymagań Unii Europejskiej w zakresie dekarbonizacji, zawarte w Pakiecie Zimonym [5], co zdaje się potwierdzać sposób rozumowania Ministerstwa Energii: maksymalizować wykorzystanie węgla w krajowej energetyce, ale przy uwzględnieniu ograniczeń wynikających z unijnej polityki klimatycznej. Powstaje jednak pytanie, czy jest to działanie optymalne kosztowo.

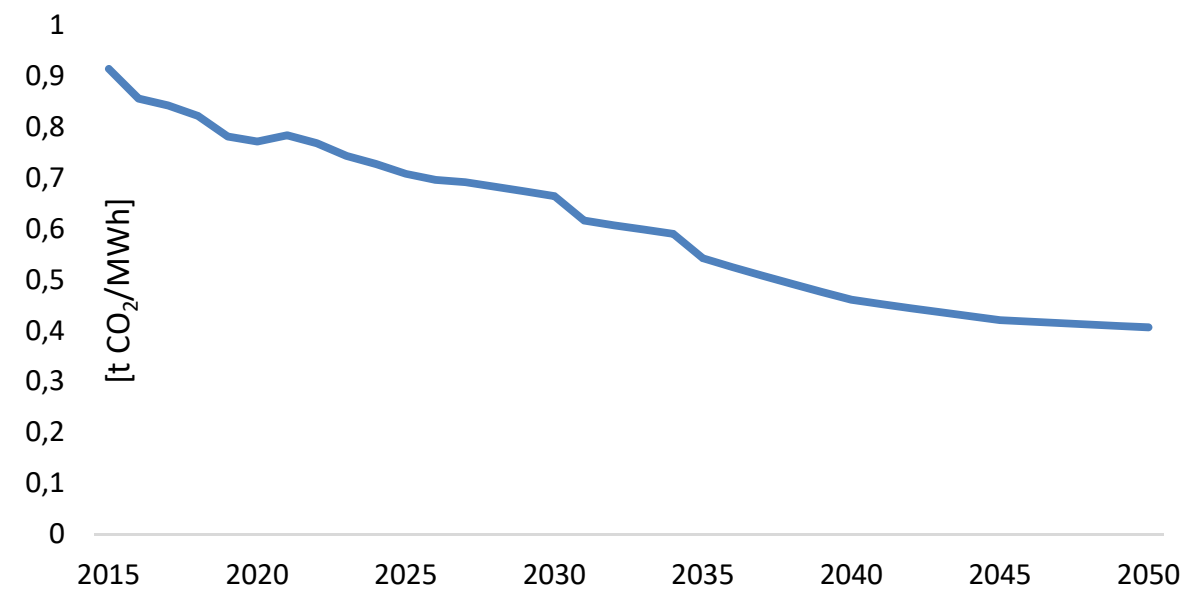

Rysunek 8. Emisyjność miksu w scenariuszu bazowym

Koszty produkcji energii w scenariuszu referencyjnym ATOM'2031 oraz w jego wariantach

Struktura paliw, źródeł i wytwarzania energii i emisyjności dla scenariusza referencyjnego oraz przyjęte założenia finansowe dotyczące kosztów paliw, emisji i kapitału pozwalaja na obliczenie kosztów energii w całym systemie (KSE) oraz jednostkowych kosztów produkcji energii.

Wyniki analiz dla scenariusza bazowego zobrazowano na wykresach 9-11, na których przedstawiono:

- nakłady inwestycyjne poszczególnych technologii wytwarzania;

- koszt zakupu energii elektrycznej w gospodarce; 
- prognozowany uśredniony (średnia ważona) koszt sprzedaży energii elektrycznej do odbiorców końcowych.

Nakłady inwestycyjne w formule overnight, czyli ponoszone po budowaniu obiektu przez wykonawcę) i koszty energii (bez kosztów dystrybucji) dla gospodarki, przedstawiono na rysunkach 9 i 10 .

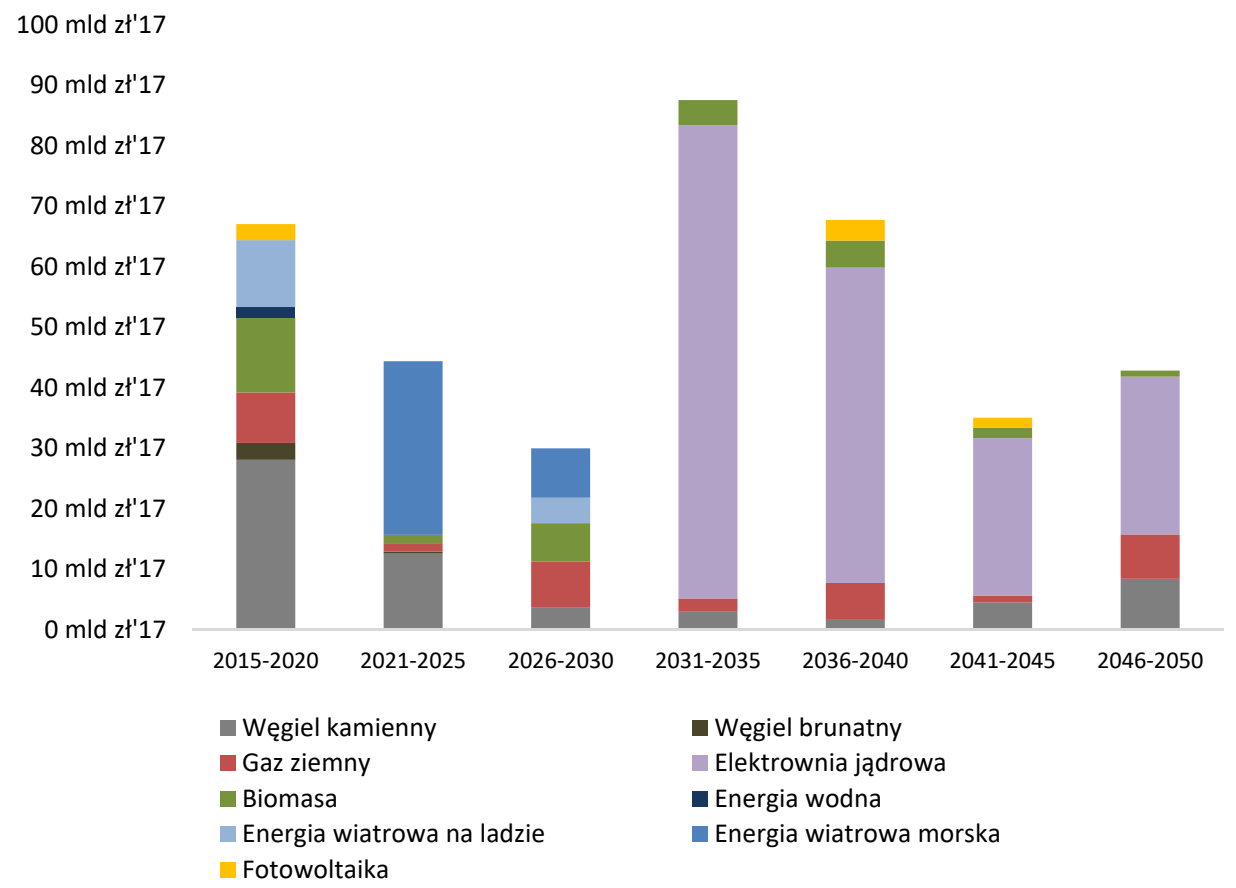

Rysunek 9. Nakłady inwestycyjne na źródła wytwórcze w energetyce w okresie prognozy w kolejnych pięcioleciach (realizacja scenariusza referencyjnego ATOM'2031). Wysokość nakładów podano w cenach statych z roku 2017 (zł'17).

Należy oczekiwać wzrostu łącznych kosztów w sektorze wytwarzania energii z 37 mld zł w roku 2015 do $68 \mathrm{mld}$ zł w roku 2030 i to pomimo spowolnienia tempa inwestycji (decydują koszty eksploatacyjne). Nakłady inwestycyjne, a w szczególności koszty dla całej gospodarki, o silnym tempie wzrostu, w sposób istotny przekładają się na cenę energii i obciążenie poszczególnych grup odbiorców. 


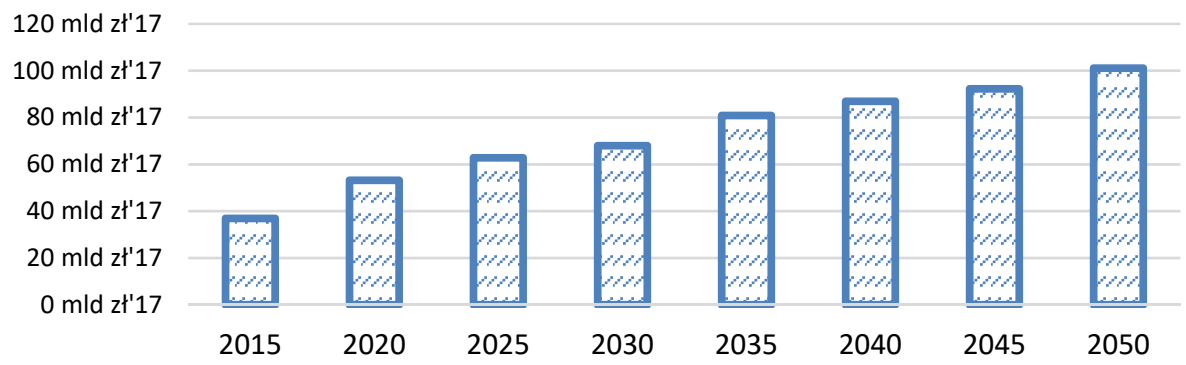

Rysunek 10. Łączny koszt energii elektrycznej dla całej gospodarki i gospodarstw domowych przy średniej cenie sprzedaży energii elektrycznej. Wysokość kosztów podano w cenach stałych z roku 2017 (zł’17).

Prognozę średnich kosztów energii, rozłożonych dla wszystkich odbiorców pokazano na rysunku 11. W celu weryfikacji użytego modelu, koszty energii w scenariuszu referencyjnym ATOM'2031, zostały zestawione w kosztami prognozowanymi modelem PRIEMS, opracowanym przez Komisję Europejską dla Polski [10] w scenariuszu bussines as usual.

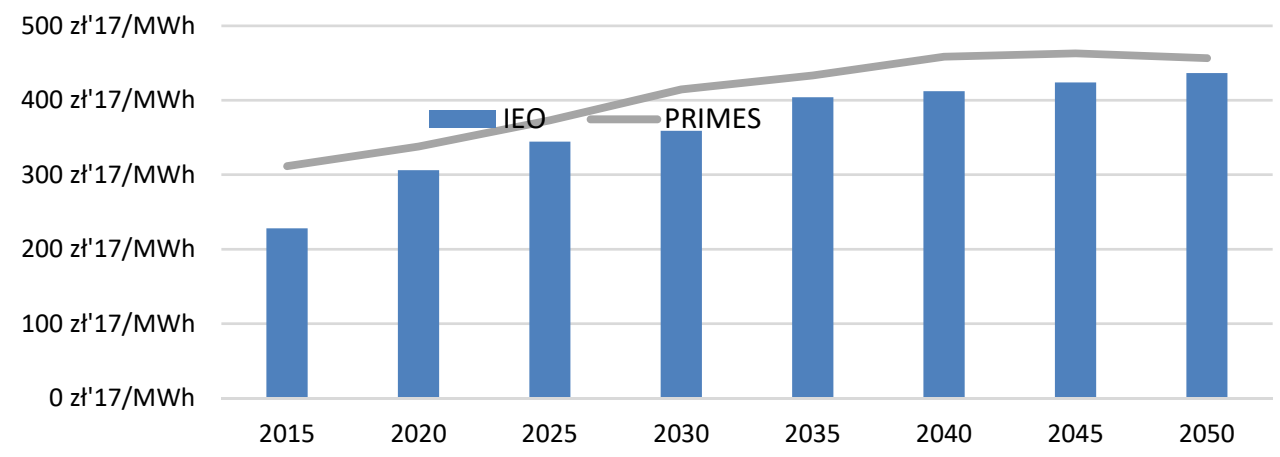

Rysunek 11. Porównanie średnich cen sprzedaży energii elektrycznej wg. IEO i wg. modelu PRIMES. Koszty energii podano w cenach stałych z roku 2017 (zł'17).

Okazuje się, że uzyskany miks energetyczny odpowiadający scenariuszowi referencyjnemu ATOM'2031 i wynikający z przyjętych przez Ministerstwo Energii i podanych do wiadomości publicznej założeń, mających uwzględniać wymogi polityki energetycznoklimatycznej UE do 2030 roku, jest zbieżny ze scenariuszem referencyjnym modelu PRIMES z roku 2016 dla Polski, który miał być punktem wyjścia do wdrożenia polityki klimatycznej. 
Najtrudniejszy dla odbiorców energii wydaje się okres do roku 2030. W tej sytuacji konieczna wydaje się optymalizacja miksu proponowanego kierunkowo (hasłowo) przez Ministerstwo Energii w scenariuszu referencyjnym ATOM'2031. Uzyskane wyniki zestawiono z alternatywnymi scenariuszami, w których planowany potencjał energetyki jądrowej zastapiono blokami gazowymi (GAZ’2031) i morskimi farmami wiatrowymi (MFW'2031), co obrazuje rysunek 12.

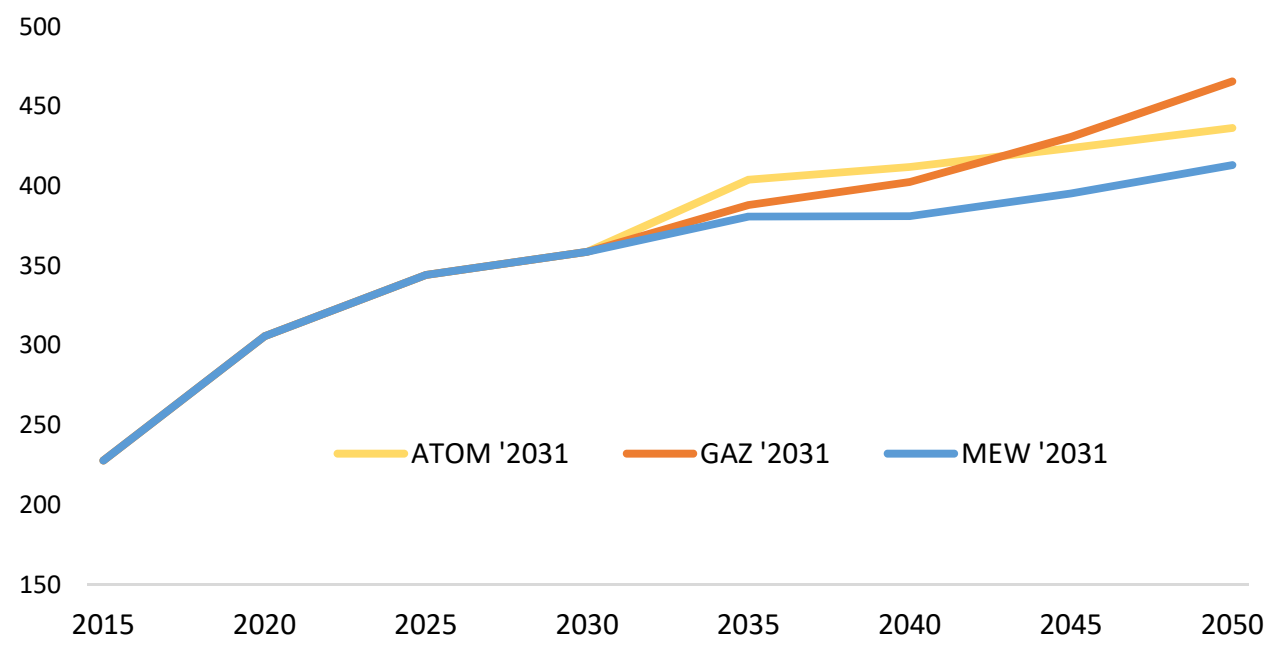

Rysunek 12. Porównanie średnich cen sprzedaży energii elektrycznej wg. scenariusza referencyjnego ATOM'2031 oraz scenariuszy, w których energia jądrowa jest zastąpiona: 1) gazem (scenariusz referencyjny GAZ'2031) lub 2) morską energetyką wiatrowa (scenariusz referencyjny MEW'2031). Koszty energii podano w cenach stałych z roku 2017 (z’’17).

Warto zauważyć, że zarówno gaz jak i morskie farmy wiatrowe to obecnie jedne z najdroższych technologii (energia elektryczna z gazu uchodzi na znacznie droższą od energii z węgla, a morskie farmy wiatrowe to jedna z najdroższych technologii OZE). Ale nawet takie rozwiązania po roku 2030 daja znacznie niższe koszty energii niż energia jądrowa. Pełne zastąpienie elektrowni jądrowych jednostkami gazowymi może okazać się jednak bardziej kosztowne w dalszej perspektywie roku 2050, w przypadku istotnych wzrostów cen paliwa gazowego. Szybko rosnące koszty energii z węgla spowodują, że obecnie budowane elektrownie węglowe będą niekonkurencyjne jeszcze przed rokiem 2030 i nie uda się ich w pełni zamortyzować. 
W tym właśnie okresie rozwój generacji rozproszonej, o krótkich cyklach inwestycyjnych, opartej przede wszystkim na OZE, wydaje się być najbardziej uzasadnioną alternatywą zarówno dla nowych inwestycji węglowych (Elektrownia Ostrołęka), jak i dla przynajmniej części inwestycji modernizacyjno-odtworzeniowych (planowanych do wsparcia rynkiem mocy). Analizy pokazuja, że nawet w ramach obecnie realizowanej polityki są znaczące możliwości optymalizacji (obniżania) kosztów energii dla odbiorców.

Jednak jeżeli nawet proponowana obecnie przez Ministerstwo Energii struktura miksu energetycznego - w obliczu polityki Unii Europejskiej i kosztów - będzie ulegała zmianie i będzie dostosowywana do realnych warunków w celu obniżenia presji kosztowej, to i tak wzrostu kosztów energii w Polsce nie da się już całkiem powstrzymać. Potrzebne będa zatem znacznie poważniejsze korekty i działania dostosowawcze, zwłaszcza jeżeli na problem popatrzeć z perspektywy taryf dla różnych grup odbiorców - rysunek 13.

450 PLN'17/MWh

400 PLN'17/MWh

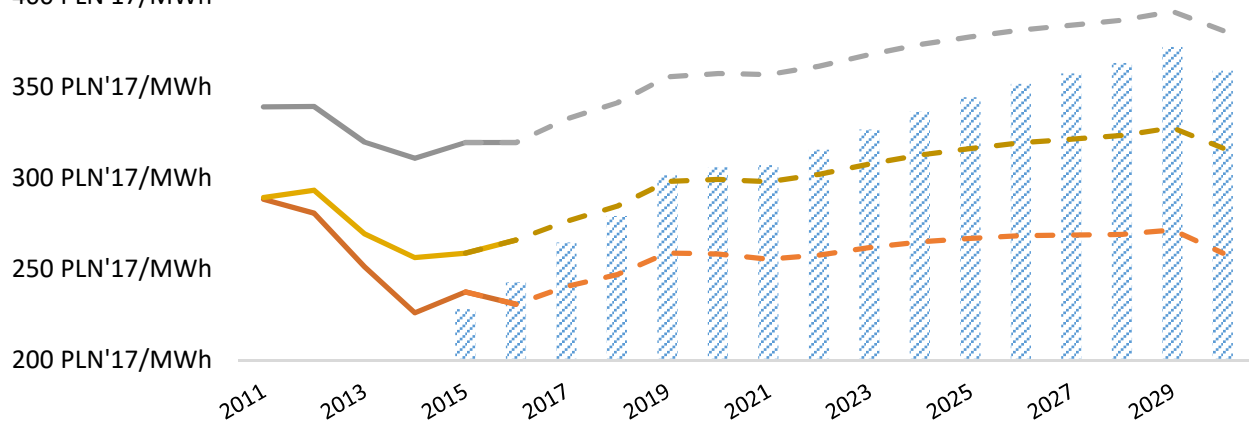

$\mathscr{W} \mathscr{K}$ średnia cena energii w gospodarce - prognoza IEO

- Grupa taryfowa B - dane statystyczne

Grupa taryfowa C - dane statystyczne

- - - Grupa taryfowa B - dezagregacja wg. trendu prognozy

- - Grupa taryfowa C - dezagregacja wg. trendu prognozy

- Grupa taryfowa G - dane statystyczne

- - - Grupa taryfowa G - dezagregacja wg. trendu prognozy

Rysunek 13. Dezagregacja prognozy średnich cen energii elektrycznej w Polsce na poszczególne zespoły taryfowe (grupy odbiorców energii). Koszty energii podano w cenach stałych z roku 2017 (PLN'17). 
Na potrzeby tego opracowania prognozy cen energii elektrycznej dla grup taryfowych C, B oraz G, odpowiadających wybranym grupom odbiorców (handel i usługi, przemysł, gospodarstwa domowe) posłużono się danymi historycznymi URE i sprowadzono je do poziomu z roku 2017 poprzez odfiltrowanie inflacji. Następnie ww. dane poddano analizie statystycznej opartej na regresji liniowej, przyjmując poziom ufności 95\% w celu uzyskania właściwego trendu w okresie 2020-2030. Otrzymany wynik zestawiono z trendem prognozy średnich cen sprzedaży energii elektrycznej na rynku, zaś poszczególnym składowym przypisano następujące wagi:

- trend wynikajaccy z analizy statystycznej - 0,3;

- trend wynikajacy z prognozy średnich cen energii elektrycznej na rynku - 0,7.

Jako horyzont czasowy do analizy skali i dynamiki kształtowania się detalicznych cen sprzedaży energii elektrycznej przyjęto rok 2030.

Rozbudowana struktura taryf dystrybucyjnych, wysoce uzależniona od zmiennych uwarunkowań polityczno-rynkowych sprawia, że modelowanie w dłuższym horyzoncie czasowym jest utrudnione i potencjalnie może być obarczone błędami, tym bardziej z uwagi na trudne do przewidzenia czynniki decyzyjne transpozycja obecnego trendu na lata 2030-2050 wydaje się nieuzasadniona (analizy kosztów dystrybucji w dalszym horyzoncie czasowym, byłyby obarczone coraz wyższym błędem regulacyjnym i politycznym).

Wyniki modelowania i analiz prowadza do wniosku, że w latach 2015-2030 (2015 to rok bazowy w wykorzystywanym modelu) cena energii dla odbiorców energii (ceny stałe z roku 2017, bez inflacji) na taryfach C wzrośnie o ponad 19,2\%, a na taryfach G o 22,3\%. Przy taki wyraźnym wzroście cen energii (i towarzyszacemu im analogicznemu - o czym dalej - wzrostowi kosztów dystrybucji), energia elektryczna dla tych grup odbiorców może stać się jedną z najdroższych w UE, tym bardziej że w unijni producenci energii z OZE o niskich lub zerowych kosztach zmiennych zaczynaja już obniżać koszty energii.

Prognozowana skala wzrostu detalicznych cen energii elektrycznej w perspektywie 2030 przedstawia się następująco (stawki netto w cenach stałych z roku 2017-zł'17):

- Grupy B (przemysł) - 8,9\% (do poziomu 259 zł/MWh)

- Grupy C (MSP, usługi, handel, drobny przemysł) - 19,2\% (do poziomu 381 zł/MWh)

- Grupy G (gospodarstwa domowe): - 22,3\% (do poziomu 316 zł/MW) 


\section{Prognoza taryf dystrybucyjnych dla wybranych grup odbiorców}

Na rysunkach 13 i 14 zilustrowano trendy wzrostu opłat za dystrybucję dla grup odbiorców, którzy będa jednocześnie najbardziej obciażani wzrostem kosztów energii, czyli grup taryfowych C i G. Przy wyznaczaniu trendów dla jednostkowych opłat dystrybucyjnych posłużono się jedynie regresją liniową danych historycznych na poziomie ufności 95\%. Oparcie się na regresji liniowej (a nie przyśpieszonej) jest założeniem obarczone ryzykiem i optymistyczne dla odbiorców energii z sieci krajowej z kilku powodów. Należy bowiem pamiętać, że scenariusz referencyjny opiera się na generacji scentralizowanej, czyli kosztochłonnej dla rozwoju sieci energetycznych, a ponadto majatek sieciowy obciążony jest wielomiliardowym ryzykiem w postaci dotychczas niezaspokojonych roszczeń tzw. „służebności przesyłu”. Uznano jednak, że miliardowe środki unijne z okresu 2014-2020 aktualnie zagospodarowane przez operatorów sieci pod potrzeby przyłączania OZE złagodzą tempo narastania ww. kosztów.

350 zł'17/MWh

300 zt'17/MWh

$250 \mathrm{zt} 17 / \mathrm{MWh}$

200 zł'17/MWh

$150 \mathrm{zt} ' 17 / \mathrm{MWh}$

$100 \mathrm{zt} ' 17 / \mathrm{MWh}$

50 zł'17/MWh

0 zł'17/MWh

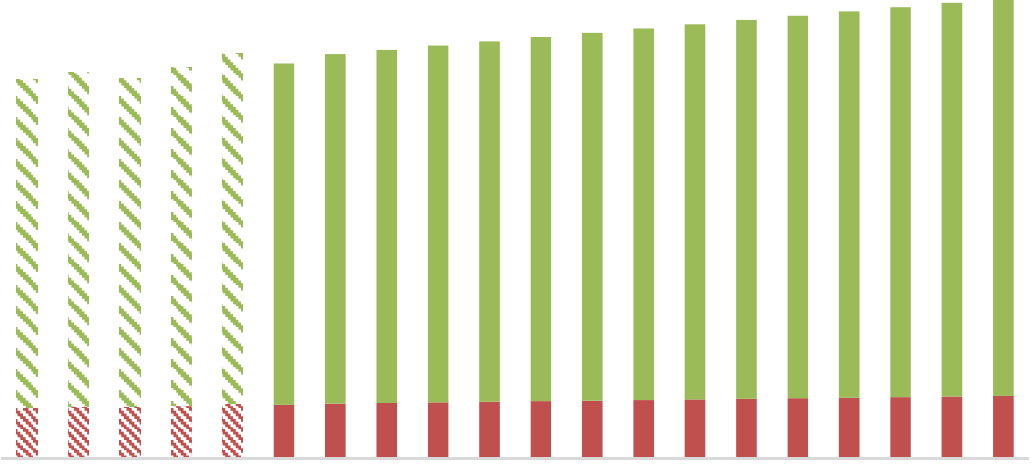

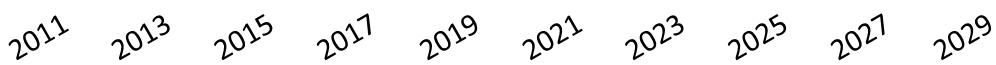

" składnik stały (opłata za moc umowną) @ składnik zmienny (opłata za zużycie)

Rysunek 14. Prognoza trendu zmienności taryf dystrybucji dla grupy taryfowej C. Koszty usługi dystrybucji podano w cenach stałych z roku 2017 ( $z \nmid 17)$. 
Rozkładu całkowitego, jednostkowego kosztu dystrybucji energii elektrycznej na poszczególne składniki dokonano na podstawie przyjętych standardowych profili odbiorców oraz średnich udziałów poszczególnych składników opłat w całkowitym koszcie dystrybucji (wyznaczonych w oparciu o analizę taryf dystrybucyjnych największych OSD, zatwierdzonych na rok 2018). Przyjęte do analizy standardowe profile odbiorców rozliczających się w ramach branych pod uwage grup taryfowych:

- Grupy C - 35 kW (moc umowna), 65 MWh (roczny pobór energii elektrycznej);

- Grupy G - 4 MWh (średni roczny pobór energii elektrycznej w okresie do roku 20130).

350

300

250

200

150

100

50

0

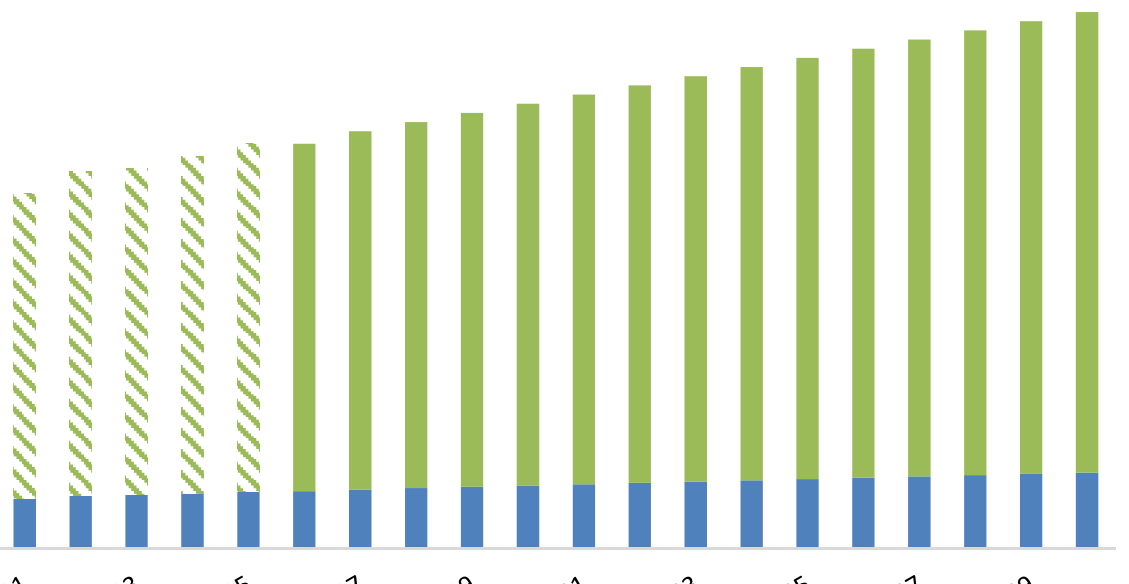

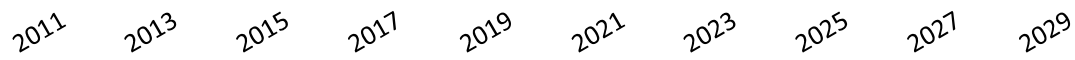

n składnik stały $\quad$ składni zmienny (opłata za zużycie)

Rysunek 15. Prognoza trendu zmienności taryf dystrybucji dla grupy taryfowej G. Koszty usługi dystrybucji podano w cenach stałych z roku 2017 (z’’17).

Wg przyjętej metody (z konieczności uproszczonej) koszty dystrybucji będą rosły najszybciej w sektorze gospodarstw domowych (taryfy G), ale tempo wzrostu kosztów dystrybucji np. dla małych firm, towarowych gospodarstw rolnych i samorządów jest też znaczace i niestety nakłada się na przewidywany właśnie dla tej grupy odbiorców najwyższy wzrost cen za energię (i opłaty pochodne). 
Prognozowana skala wzrostu jednostkowych kosztów dystrybucji w perspektywie 2030 przedstawia się następująco (stawki netto w cenach stałych z roku 2017 - zł'17):

- Grupy C (MSP, usługi, handel, drobny przemysł) - 13\% (do poziomu 291 zł/MWh);

- Grupy G (gospodarstwa domowe) - 32\% (do poziomu 317 zl/MWh).

W analizach nie uwzględniono korelacji kosztów sieciowych z planowanymi przez Ministerstwa Energii szybszym niż dotychczas wzrostem zapotrzebowania na energię elektryczną. Ta korelacja, w szczególności łącznie z zastrzeżeniami podatnymi na wstępie, a dotyczącymi kontynowania scentralizowanego modelu generacji i nierozwiązanego problemu roszczeń właścicieli gruntów, może istotnie podnieść prognozowaną skalą wzrostu jednostkowych kosztów dystrybucji, nawet o 50\%.

\section{Podsumowanie i wnioski}

Opracowany model kosztowy dla krajowego systemu energetycznego, w który wpisane zostały założenia obecnie realizowanej polityki energetycznej, pozwolił na potwierdzenie tezy, że dostrzeżony w roku 2018 wyraźny wzrost cen energii w kontraktach na rynku dnia następnego w II kwartale (w stosunku do poprzedniego roku) oraz w kontraktach terminowych na III kwartał 2018 sa zwiastunem dłuższego trendu wzrostowego cen, który może mieć miejsce aż do końca przyszłej dekady.

Obecne wzrosty cen mają częściowo swoje obiektywne uzasadnienie w cenowym koniunkturalnym cyklu węglowym (wzrost cen węgla oraz uprawnień do emisji $\mathrm{CO}_{2}$ ), ale przede wszystkim mają one charakter fundamentalny i są nieuchronne jako pochodna realizowanej polityki energetycznej, stawiającej już od kilku lat na inwestycje i przyszły miks energetyczny zdominowany przez drożejące źródła węglowe (do roku 2030) oraz jądrowe (w latach 2031-2050). W okresie do roku 2030 należy oczekiwać wzrostu łącznych kosztów w sektorze wytwarzania energii z 37 mld zł w roku 2015 do $68 \mathrm{mld}$ zl, i to pomimo spowolnienia tempa inwestycji w tym okresie.

Inwestycje w drożejące źródła, w sytuacji gdy w naszym regionie Unii Europejskiej rośnie udział w strukturze wytwarzania OZE o niskich czy niemal zerowych kosztach zmiennych spowoduje, że krajowe firmy energetyczne tracić mogą konkurencyjność, co 
wpłynie na pogorszenie w Polsce bilansu handlowego na unijnym rynku energii elektrycznej, a to pośrednio wzmocni jeszcze bardziej trendy spadkowe w wycenie rynkowej krajowych koncernów energetycznych.

Jednak wobec ograniczanych możliwości technicznych w wymianie handlowej z sąsiadami powyższe zjawiska spowoduja, że najpoważniejszym skutkiem i największym problemem polskiej energetyki i gospodarki w obliczu polityki energetycznej indukującej wzrostów kosztów w systemie staną się ceny energii i taryf dla końcowych odbiorców energii. Wyniki modelowania i analiz prowadzą do wniosku, że w latach 2018-2029 cena energii dla odbiorców energii (ceny stałe z roku 2017, bez inflacji) na taryfach C (MŚP, usługi, handel, drobny przemysł) wzrośnie o ponad 19,2\%, do poziomu 381 zł/MWh, a na taryfach G (gospodarstwa domowe) o 22,3\% do poziomu 316 zł/MWh w 2030 roku. Niestety ten trwały trend wzrostowy cen energii dla odbiorców będzie w tym okresie też w sposób ciagły wzmacniany wzrostem kosztów dystrybucji. Koszty dystrybucji dla grupy taryfowej $\mathrm{C}$ w analizowanym okresie wzrosna co najmniej ponad 13\% (do poziomu 291 zl/MWh), a dla grupy G: 32\% (do poziomu 317 zł/MWh). Założenia przyjęte do modelowania i prognozowania kosztów są optymistyczne, zwłaszcza jeśli chodzi o koszty dostosowania się istniejących elektrowni węglowych do nowym wymogów emisyjnych jak i koszty dystrybucji, które mogą być wyższe. Pomimo tego sumaryczne koszty dostaw energii mogą okazać się wkrótce jednymi z najwyższych w UE i trudnymi do zaakceptowania przez odbiorców energii.

Analizy pokazuja, że nawet w ramach obecnie realizowanej polityki są znaczące możliwości optymalizacji (obniżania) kosztów energii dla odbiorców. Poza zatrzymaniem inwestycji w nowe źródła węglowe rozważyć należy znaczące ograniczenie nakładów na modernizacje istniejących bloków węglowych, np. w ramach rynku mocy oraz na dostosowanie się źródeł węglowych do nowych wymogów dyrektywy o emisjach przemysłowych (szacuje się, że tylko to zwiększy koszty wytwarzania energii o ok. 15\% o ile kontynuowany będzie węglowy wariant rozwoju energetyki), a przyspieszyć rozwój generacji rozproszonej opartej na OZE oraz inwestycji prosumenckich u odbiorców narażonych na najwyższe wzrosty cen energii.

Jednak jeżeli nawet proponowana dotychczas przez Ministerstwo Energii struktura miksu energetycznego w obliczu polityki Unii Europejskiej i kosztów będzie ulegała zmianie i dostosowaniu do realnych warunków i w konsekwencji obniżyć obniżyć presję 
kosztową, to i tak w krótkim i średnim okresie nie da się już całkiem powstrzymać wzrostu kosztów energii w Polsce. Potrzebne będą zatem znacznie poważniejsze niż wskazane w artykule korekty w polskiej polityce energetycznej.

Opracowany model i uzyskane wyniki powinny być poddane okresowej weryfikacji i kalibracji na okoliczność zmian w polityce energetycznej. Potrzebne są dalsze prace badawcze na rzecz bardziej dogłębnego rozpoznania dostrzeżonych przez autorów problemów metodologicznych i interpretacyjnych. Szczegółowych dalszych badań wymaga wyjaśnienie powodów dla których koszty energii (także w dłuższym okresie) są wyższe od cen.

Postawić tu można co najmniej dwie tezy do dalszych badań:

(1) pionowo zintegrowane koncerny energetyczne przerzucają koszty z wytwarzania na dystrybucję;

(2) system energetyczny nie inwestuje, aby w sprawozdaniach finansowych poprawiać wyniki.

Trudne do wytłumaczenia wyłącznie na gruncie nauk ekonomicznych okazały się też dostrzeżone, ale nie poddane w artkule pogłębionym analizom, dwie sprzeczne tendencje na rynku energii: rosnące zyski koncernów energetycznych, a jednocześnie drastyczny spadek ich wartości giełdowej. W artykule przejęto założenie, że o energetyce w istotny sposób decyduje polityka energetyczna, która uwzględnia uwarunkowania międzynarodowe i że do niej w pełni dostosowuja się inwestorzy, a w szczególności grupy energetyczne znajdujące się $\mathrm{w}$ zarządzie resortu energii. Autorzy zdają sobie sprawę że zachowania niezależnych producentów energii i prosumentów także poddaja się polityce energetycznej, ale mogą być one bardziej zorientowane na rynek, a tym samym w różnym zakresie wpływać i na politykę i na ceny energii. Tego typu czynniki wymagaja jednak dalszych badań modelowych i empirycznych w zakresie złożonych relacji: polityka energetyczna - rynek energii - koszty energii - konsumenci energii gospodarka - społeczeństwo.

\section{Bibliografia}

[1] Towarowa Giełda Energii, Indeks IRDN w okresie 01.05-31.05.2018

[2] Polityka energetyczna Polski do 2030 roku (2009), Ministerstwo Gospodarki, Warszawa 
[3] Dlugoterminowy scenariusz zaopatræenia Polski w czyste nośniki energii (2013), Instytut Energetyki Odnawialnej, Warszawa

[4] Wiśniewski G., Ligus M., Michałowska-Knap K., Arcipowska A. (2013) Analiza porównawcza kosztów morskiej energetyki wiatrowej i energetyki jadrowej, Instytut Energetyki Odnawialnej, Greenpeace Polska i Fundacja im. Heinricha Bölla, Warszawa

[5] Clean Energy For All Europeans (2016), portal European Commission, zakładka Energy, podstrona Commission proposes new rules for consumer centred clean energy transition, https://ec.europa.eu/energy/en/news/commission-proposes-new-rules-consumer-centred-clean-energy-transition

[6] Program dla sektora górnictwa wegla kamiennego w Polsce (2018), Ministerstwo Energii, Warszawa

[7] World Energy Outlook 2016 (2016), International Energy Agency, Paris

[8] Wartości opatowe (WO) i wskaźniki emisji CO2 (WE) w roku 2014 do raportowania w ramach Systemu Handlu Uprawnieniami do Emisji za rok 2017 (2016), KOBiZE, IOŚ, Warszawa, http://www.kobize.pl/en/article/2016/id/800/wartosci-opalowe-wo-iwskazniki-emisji-co2-we-w-roku-2014-do-raportowania-w-ramach-systemuhandlu-uprawnieniami-do-emisji-za-rok-2017

[9] POLL: Analysts trim near-term EUA price forecasts as auctions put a damper on market (2017), Carbon Pulse, http://www.carbon-pulse.com/37341

[10] EU Reference Scenario 2016 (2016), E3M Lab National Technical University of Athens EU28: Reference scenario (REF2016) Summary Report Primes Ver. 4 Energy Model, http:/ / ec.europa.eu/energy/en/data-analysis/energy-modelling 